Article

\title{
Organic Beekeeping Practices in Romania: Status and Perspectives towards a Sustainable Development
}

\author{
Cristina Bianca Pocol ${ }^{1}$ (D), Peter Šedík ${ }^{2, *(D)}$, Ioan Sebastian Brumă ${ }^{3, *(D)}$, Antonio Amuza 4 \\ and Aurica Chirsanova ${ }^{5}$ (D) \\ 1 Department of Animal Production and Food Safety, University of Agricultural Sciences and Veterinary \\ Medicine of Cluj Napoca, 400372 Cluj Napoca, Romania; cristina.pocol@usamvcluj.ro \\ 2 Center for Research and Educational Projects, Faculty of Economics and Management, Slovak University \\ of Agriculture in Nitra, Tr. A. Hlinku 2, 94976 Nitra, Slovakia \\ 3 "Gh. Zane" Institute for Economic and Social Research, Romanian Academy, Iași Branch, \\ 700481 Iași, Romania \\ 4 Department of Sociology and Social Work, University of Bucharest, 030018 Bucharest, Romania; \\ amuza.antonio@gmail.com \\ 5 Department of Food and Nutrition, Technical University of Moldova, 168, Stefan cel Mare Bd., \\ MD-2004 Chișinău, Moldova; aurica.chirsanova@toap.utm.md \\ * Correspondence: sedik.peter@gmail.com (P.Š.); sebastianbruma1978@gmail.com (I.S.B.)
}

check for

updates

Citation: Pocol, C.B.; Šedík, P.; Brumă, I.S.; Amuza, A.; Chirsanova, A. Organic Beekeeping Practices in Romania: Status and Perspectives towards a Sustainable Development. Agriculture 2021, 11, 281. https:// doi.org/10.3390/agriculture11040281

Academic Editors:

Małgorzata Bieńkowska and Anna Gajda

Received: 2 March 2021

Accepted: 22 March 2021

Published: 25 March 2021

Publisher's Note: MDPI stays neutral with regard to jurisdictional claims in published maps and institutional affiliations.

Copyright: (c) 2021 by the authors. Licensee MDPI, Basel, Switzerland. This article is an open access article distributed under the terms and conditions of the Creative Commons Attribution (CC BY) license (https:// creativecommons.org/licenses/by/ $4.0 /)$.

\begin{abstract}
Romanian beekeeping faces a lot of challenges nowadays due to the problems related to climate change, the use of pesticides in agriculture, but also to the pandemic crisis. In this context, organic beekeeping represents an important alternative to traditional apicultural practices. The purpose of the study was to present the current situation of organic beekeeping in Romania, but also to identify some aspects related to sustainability. The research methodology was based on secondary and primary data. An online survey was conducted in 2020 on a sample of 433 Romanian beekeepers. The main findings showed that the majority of participants were aware of organic principles and were familiar with the concept of sustainability in beekeeping. However, only a small percentage of beekeepers were certified in the organic system. The evaluation of the concept of sustainability showed that the most important factor for the surveyed beekeepers was the environmental aspect, followed by the economic and social components. The pandemic crisis has negatively impacted the beekeepers' activities due to travel restrictions and the limited access to the apiaries. If, in economic terms, they were affected by the sales drop in the first months of the crisis, there were also some positive effects such as the increase in demand for health-related products.
\end{abstract}

Keywords: beekeepers; organic practices; sustainability; pandemic crisis; challenges

\section{Introduction}

\subsection{The Importance of Beekeeping}

Beekeeping is an archaic occupation as historical accounts of ancient Egypt, Greece, and Rome reveal extensive knowledge on European honeybee (Apis mellifera) [1]. According to these records, honey is both a currency of commercial exchange and a commodity offered as a high-priced gift or as payment for certain levies [2]. There has been a strong connection between humans and bees since time immemorial, and this relationship relies heavily on the fact that $80 \%$ of the world's plants are pollinated by bees [3], and, also, on the highly-nutritional, therapeutical [4], and economic value of their products [5]. In the case of transition economies and developing countries, beekeeping becomes a key occupation for generating additional revenues and a better resilience for the rural inhabitants [6,7]. Beekeeping is an activity which requires little capital, has a low-cost maintenance and generates revenues in a relatively short period of time [8]. Along with the economic benefits, beekeeping provides social advantages as well, since it ensures food security [9], improves quality of life in rural space [8], produces social cohesion, supports women empowerment, 
and reduces the migration of the rural population to urban areas [8-10]. Not in the least, beekeeping is considerably beneficial for the environment by maintaining the ecological equilibrium and supporting biodiversity [11].

According to Patel et al. [12], beekeeping has the unique capacity of contributing to achieving 15 out of the total of 17 goals pointed out by the Sustainable Development Goals of the United Nations; among the most important goals are the following: eradication of poverty and hunger, contribution to health maintenance and a healthy lifestyle, achieving sustainable systems of production and consumption, development of entrepreneurship and gender equality, innovation and building sustainable communities [12].

\subsection{Sustainable Dimensions of Beekeeping}

For measuring sustainability in the field of agriculture, it generally implies assessing certain criteria that belong to the three pillars: economy, society, and environment. This assessment can take place at farm level or even on larger scales, with the assistance of certain reliable measuring tools $[13,14]$. For the past thirty years, there have been developed a great number of such instruments that require a continuous polishing process for a proper introduction of all data laid down by the above-mentioned pillars $[15,16]$.

Unlike other agricultural sectors, the assessment of sustainability for beekeeping businesses has not been completely researched in the scientific community, to our knowledge. Rahimi et al. [17] drew the attention on the importance of using certain conceptual assessing models in the case of sustainability for the apiculture sector. This feature is backed by Kouchner et al. $[18,19]$ as well, underlining the lack of tools necessary for assessing sustainability in this area and suggesting an assessment system dedicated exclusively to honeybee farming. This system was comprised of six dimensions as follows: "quality of life", "economic viability", "ability to ensure production", "beekeeping sector and society issues", "environmental impacts", and "local development and integration" [18,19]. Rahimi et al. [17] came up with a model of sustainability assessment based on criteria such as: beekeeping productivity, monetary value of the production obtained, product quality and development of added value, marketing of honeybee products, beekeepers' attitude towards environment, stakeholders' socio-cultural level of development in apiculture, quality of the extension and education services addressing beekeepers, employment of new technologies. Besides these features of the sustainability pillars, there were also elements related to the institutional framework, namely understanding the current legislation, supporting programs, and the role played by stakeholders and NGOs [17]. In addition, according to Juríčková et al. [20], organic farming as 'sustainable' farming systems is nowadays subsidized as it provides a potential solution for supporting biodiversity and protects the environment.

\subsection{Beekeeping Practices and Sustainability}

The analysis of the quality of beekeeping practices, and, also, of the quality of the honey bee products obtained brings up an issue of great importance for the sustainability of the beekeeping businesses [11,19]. The concept of "quality" of the apicultural products, in terms of awareness and implementation, was developed with the assistance of training and extension activities addressing producers and processors from the beekeeping sector. Among the most familiar systems for quality certification are the following: HACCP (Hazard Analysis Critical Control Point), ISO (International Organization for Standardization), PDO (Protected Designation of Origin), PGI (Protected geographical indication), and organic certification [21,22].

The organically certified apiaries are associated with sustainable beekeeping practices [23], and the beekeepers complying with the standards of honey quality are those who respect the bees and environment [24]. The organic apiculture implies abiding by certain specific principles, while the apiary management should be in agreement with the bees' biological cycle, habits, and their capacity to produce healthy food [25]. In general, mandatory certification is required in the case of organic beekeeping, where a beekeeper 
must follow principles of organic production based on European regulations; annual apiary inspections are held by an independent body [26]. Organic beekeeping includes special rules and conditions in apiary management (Figure 1). Bees in organic beekeeping must be kept in hives made by natural materials (woods, hay) and the apiary must be located in the environment that provides organic nectar and pollen (no agricultural lands, which are treated with plant protection products). Beekeepers are not allowed to destroy bees in the comb (drone brood removal or queen cells removal) as well as to clip the wings of bee queens. Foundation used in the hives must be made of organic wax. Beekeepers are allowed to feed bees with organic honey, sugar, or syrups only if the survival of the hive is in danger; otherwise, they must leave them a sufficient amount of honey and pollen for surviving the winter period. In case of veterinary cares, only organic treatments are allowed $[27,28]$.

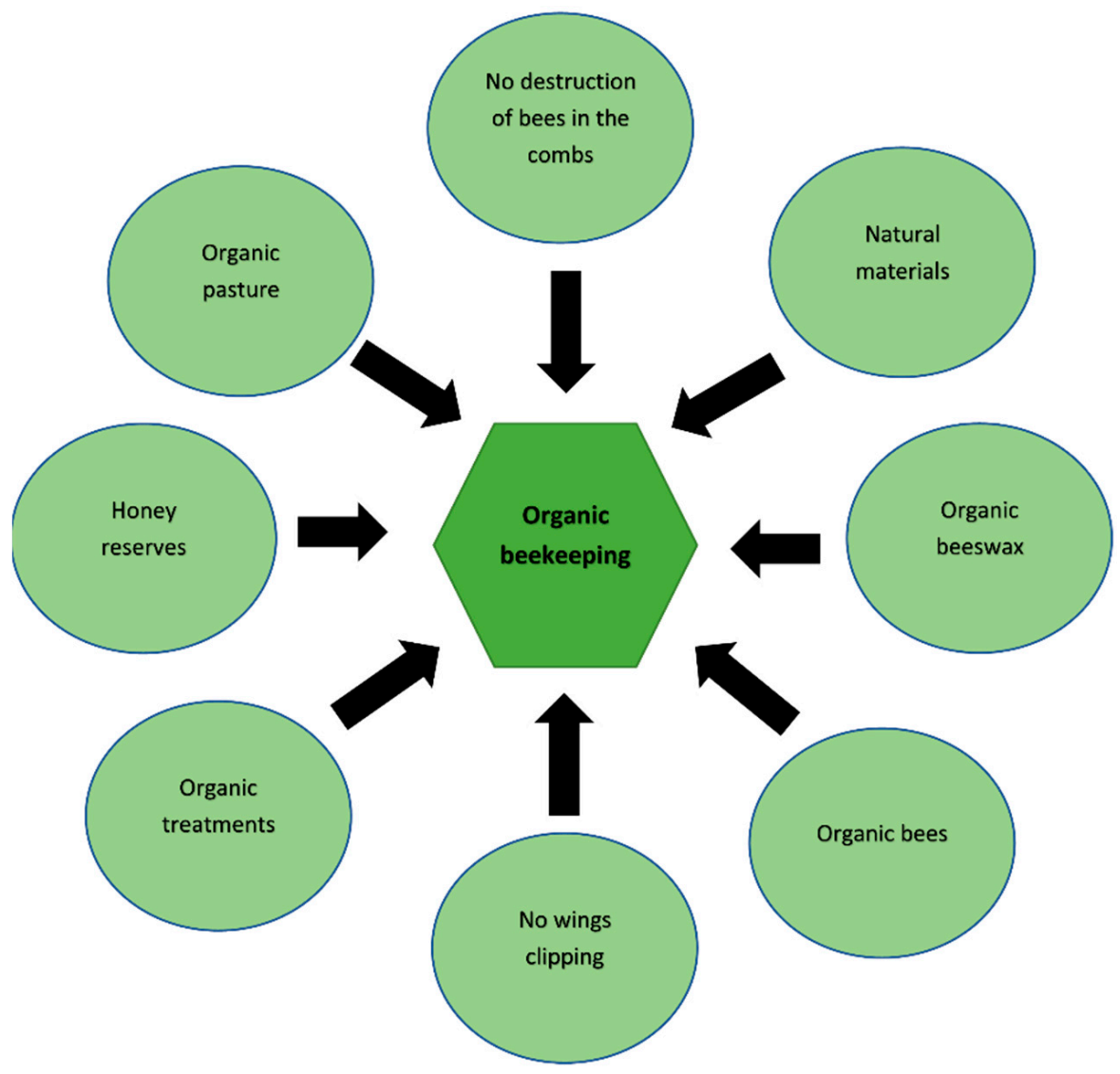

Figure 1. Practices in organic beekeeping, Source: [27,28].

Sustainable beekeeping is based on improved methods and approaches that are natural for honeybees like natural size of cells in combs or applying non-synthetic chemical treatments [29]. However, the main problems in organic beekeeping are as follows: the lack of knowledge about practices in organic beekeeping and complicated process of organic certification. In the case of Varroa control with organic methods, this can be a challenge for those beekeepers who apply only chemical-synthetic methods and who need a transition period to learn about organic principles. Nevertheless, in 2018, there existed almost 2.6 million beehives in organic apiaries and approximately $37 \%$ were situated in Europe. It is assumed that the number of beehives in organic apiaries will continue to rise due to a positive trend in demand for organic bee products and honey [30].

What should be highlighted here is that there is a category of beekeepers who use sustainable apicultural practices, and yet fail to make the necessary steps for getting organic certification or give up organic beekeeping from various reasons, such as: highproduction costs, low-sale prices, necessity for identification certain treatments, which are 
more effective for bee diseases, and consumers' fail to recognize the added value of the organically certified products [31]. The economic efficiency of the organically certified apiaries can be obtained, according to Güemes-Ricalde et al. [32], by increasing productivity and number of apiaries.

Irrespective of the fact we are discussing organic and conventional beekeeping, the employment of sustainable apicultural practices contributes to the maintenance of apiary health, as well as supplying quality and safe products for consumers [33].

\subsection{Beekeeping in Romania}

Spread throughout the entire territory of the country, beekeeping is closely connected with the history of the Romanian people for having been an ancient occupation since time immemorial. The first known record of Romanian beekeeping is attributed to Herodotus (c. 484-c. $425 \mathrm{BC}$ ), the father of history, and in the book of Anabasis written by Xenophon (c. 430-c. 354 BC), the great Greek historian, it is stated that "The food of the Getae is primarily based on honey, vegetables, regular milk and dairy products, and little meat since their faith in Zalmoxis prohibits it" [34].

The beekeeping sector in Romania has undergone several periods of progress and regress as well, depending on the political and economic circumstances. If, before the establishment of the communist regime in Romania, almost all farmers (peasants) used to keep a few beehives, in 1961 there were registered 653,000 beehives across the country's territory [34]. During the communist regime, the beekeeping sector grew significantly and, by 1989 , it reached an impressive number of 1,418,000 beehives. The political, economic, and societal changes that occurred after 1990 had a strong impact on this sector of Romanian agriculture. Thus, by 1994, the number of beehives had dropped to 614,000 , reaching levels comparable to the sixties [35]. Since 2000, the bee colonies in Romania have started to grow constantly, having reached the threshold of 1,962,000 by 2019. The year 2000 hit a milestone in Romanian agriculture as organic agriculture was enacted [36], and beekeeping being of the sectors of interest in this respect.

According to Rivera-Gomis et al. [37], modern beekeeping in Europe is experiencing many opportunities and threats, which are mainly related to the environment, but also to the economic and the social aspects. Nowadays, good beekeeping practices (GBPs) include those activities which sustain animal, environmental, and human health. Organic beekeeping is considered one of the modern beekeeping practices that accomplish the above-mentioned elements, having multiple beneficial impacts.

In this context, the aim of this paper was to map the position of organic beekeeping among Romanian beekeepers and to study some aspects related to sustainability in beekeeping practices. The authors formulated the following research questions (RQ):

RQ1: What is the current situation of organic beekeeping in Romania?

RQ2: Is there any correlation between having knowledge about organic principles and hearing about the concept of sustainable beekeeping development?

RQ3: How important are the three pillars of sustainability among beekeepers in Romania?

\section{Materials and Methods}

\subsection{Research Design and Data Collection Methods}

To achieve the objectives of the present study, in the first stage, the authors used a secondary source of statistical data on the number of beekeepers from the organic beekeeping sector. The data were provided by the Ministry of Agriculture and Rural Development from Romania [38] and by the National Institute of Statistics [35], which supplied information on the total number of beekeepers and beehives.

In the second stage of the current research, primary data were collected through an online survey based on a questionnaire, which was pretested on 15 beekeepers of the target population. The final sample comprised 433 Romanian beekeepers who self-selected during the completion process of the questionnaire; the link of the questionnaire was 
distributed via email to the professional associations in this branch of activity, and on the Facebook pages of beekeepers' groups. The distribution of the link was accompanied by a letter containing information about the research aim, survey's completion time, and confidentiality of answers. A similar methodological approach can be found in the paper of El Agrebi et al. [39] on the Belgian beekeepers' perception of the mortality risks of bees. Therefore, a semi-probabilistic sample built on the snowball method was obtained. The error margin was $+/-4.66 \%$, on a trust interval of the sample of $95 \%$ [39]. The sample was representative for the investigated universe, with the addition that the self-selection occurred exclusively in the online environment. By employing the snowball sampling strategy, which allowed potential respondents to learn about the research evolution and disseminate it further, the present study was in alignment with the studies made by Agrebi et al. and Lupo et al. [39,40]. The medium length for the survey's completion was estimated to be $15 \mathrm{~min}$, and the period dedicated to data collection took place from August to October 2020. The interviewing of the beekeepers was carried out exclusively online due to the sanitary crisis triggered by SARS-COV-2 virus and travel restrictions.

\subsection{Research Instrument}

The questionnaire comprised 23 questions divided in more sections as follows: the first section incorporated a filter question about processing personal data, entirely for statistical purposes used by the University of Agricultural Sciences and Veterinary Medicine of Cluj Napoca, the coordinator of the present study; the second section included questions about beekeepers' identification data, such as the location of the apiary (village or town, county), number of beehives, age, gender, educational background, experience in beekeeping, family tradition in the beekeeping business, and number of family members involved in the beekeeping farming; the next sections contained questions about beekeeping practices (conventional/organic/mixed; stationary/migratory/mixed), bee products (type of honey and secondary products obtained; distribution channels; packaging), aspects related to organic beekeeping (principles; certification; costs; benefits for the environment; creation of "ecological beekeeping areas"; recognition of EU logo for organic beekeeping) and sustainability (knowledge about sustainable development of beekeeping, importance of the three pillars). The beekeepers' perception of the concept of sustainable development is the focus of the present paper, a key feature for achieving the aim of the research.

Other previous studies conducted in Romania, particularly in the North-East Development Region, started from the assumption that the economic efficiency of beekeeping businesses is determined by the beekeepers' perception of sustainable development [41]. Prior to checking if beekeeping businesses meet, at least, a part of the criteria implied by sustainable development, the authors of this paper considered that it is necessary to make an assessment on the importance given to various dimensions of sustainability and correlations between these dimensions by the beekeepers. Given that this research started after the emergence of the sanitary crisis, the authors thought it was necessary to incorporate (in the questionnaire) features related to the way this pandemic affected the activity of the beekeepers (open ended question related to the influence of the pandemic crisis on the entire beekeeping activity). Most questions of the survey were close, dichotomous, nominal, and ordinal. The Likert scale was used for assessing the importance of the three components of sustainability-economic, social, and environmental. The open questions for qualitative data primarily referred to the degree of knowledge on issues such as costs implied by organic beekeeping and the way in which the current sanitary crisis impacted the beekeepers' activity.

\subsection{Data Analysis Methods}

The secondary data were analyzed and also employed for creating maps with the assistance of QGIS 3.16.0 "Hannover" [42]. These maps showed the distribution of beekeepers and beehives on the territory of Romania depending on the type of beekeeping implemented, namely conventional versus organic beekeeping. 
To examine the primary data and obtain the results, the analysis was carried out using statistical software XLSTAT, version 2021.1. The significance level was set to 5\%. Assessing the differences between sets of categorical data was carried out by applying Chi-Square test of independence. Furthermore, multiple correspondence analysis (MCA) was applied in order to evaluate and visualize associations within a set of categorical variables. MCA represents a descriptive method used for studying relationship among more than two sets of categorical variables [43]. Scaling question (very unimportant, unimportant, important, and very important) was evaluated by applying non-parametric Friedman test in order to study whether there existed differences in importance among the selected components in sustainability. A multiple pairwise comparisons using Nemenyi's procedure were performed to identify these differences. The similar approach was used in a previous marketing study focused on local farmers [44].

\section{Results}

\subsection{Results Based on Secondary Data}

If we analyze the data on the Romanian beekeeping sector, in 2019 it can be noticed that there was a high number of apiaries (Figure 2) and beehives (Figure 3) in several major areas with melliferous resources (linden and acacia forests), in the counties of Vâlcea (VL), Buzău (BZ), Tulcea (TL), Sălaj (SJ), Bacău (BC), Iași (IS), and Vaslui (VS). Practicing beekeeping in the organic system attracted the interest of merely $5.2 \%$ out of the total beekeepers in Romania. These beekeepers took care of $9.7 \%$ of the total beehives in the country. From these beehives, $9.8 \%$ were under conversion and $90.2 \%$ were organically certified.

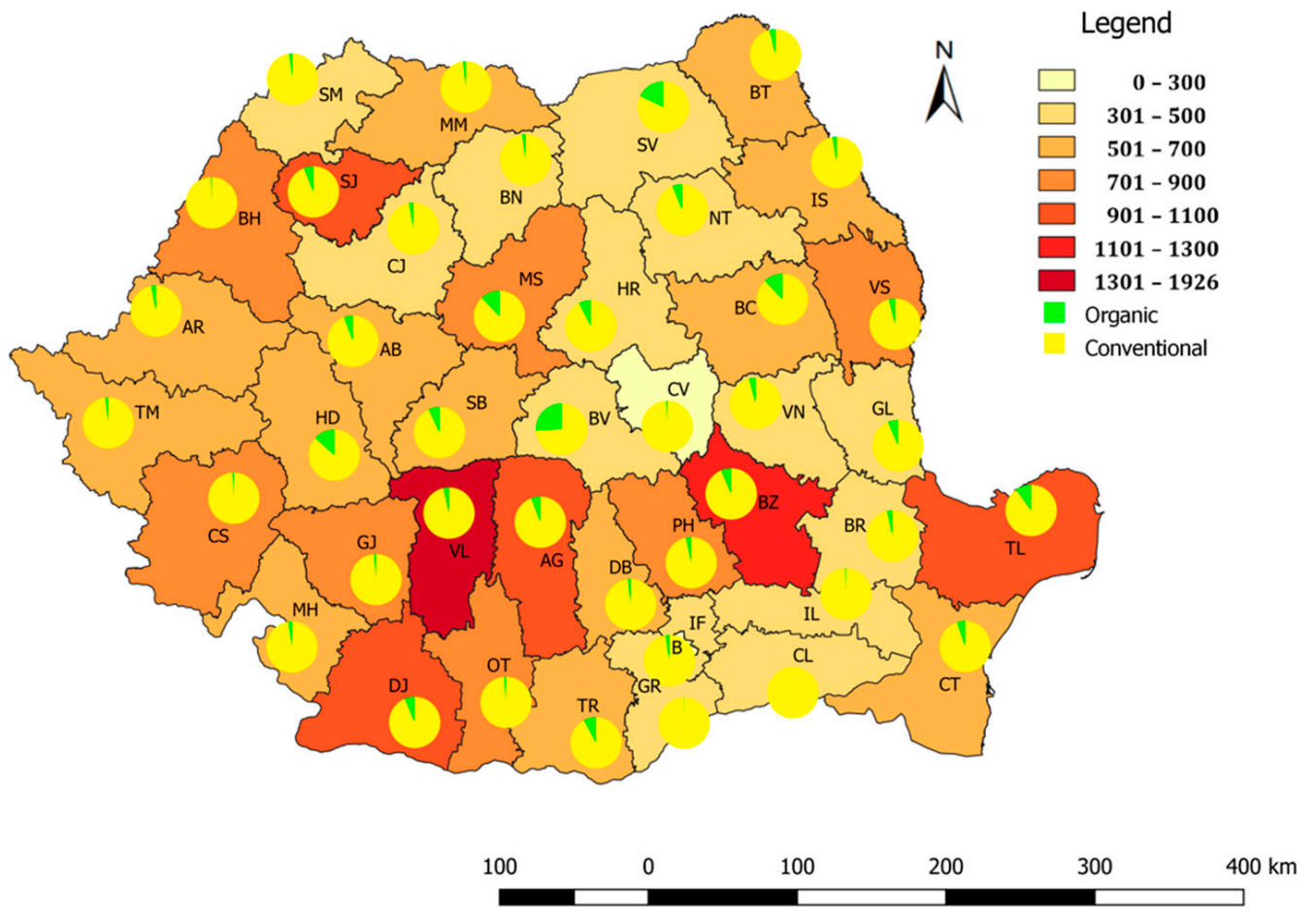

Figure 2. The distribution of apiaries in Romania (2019). 


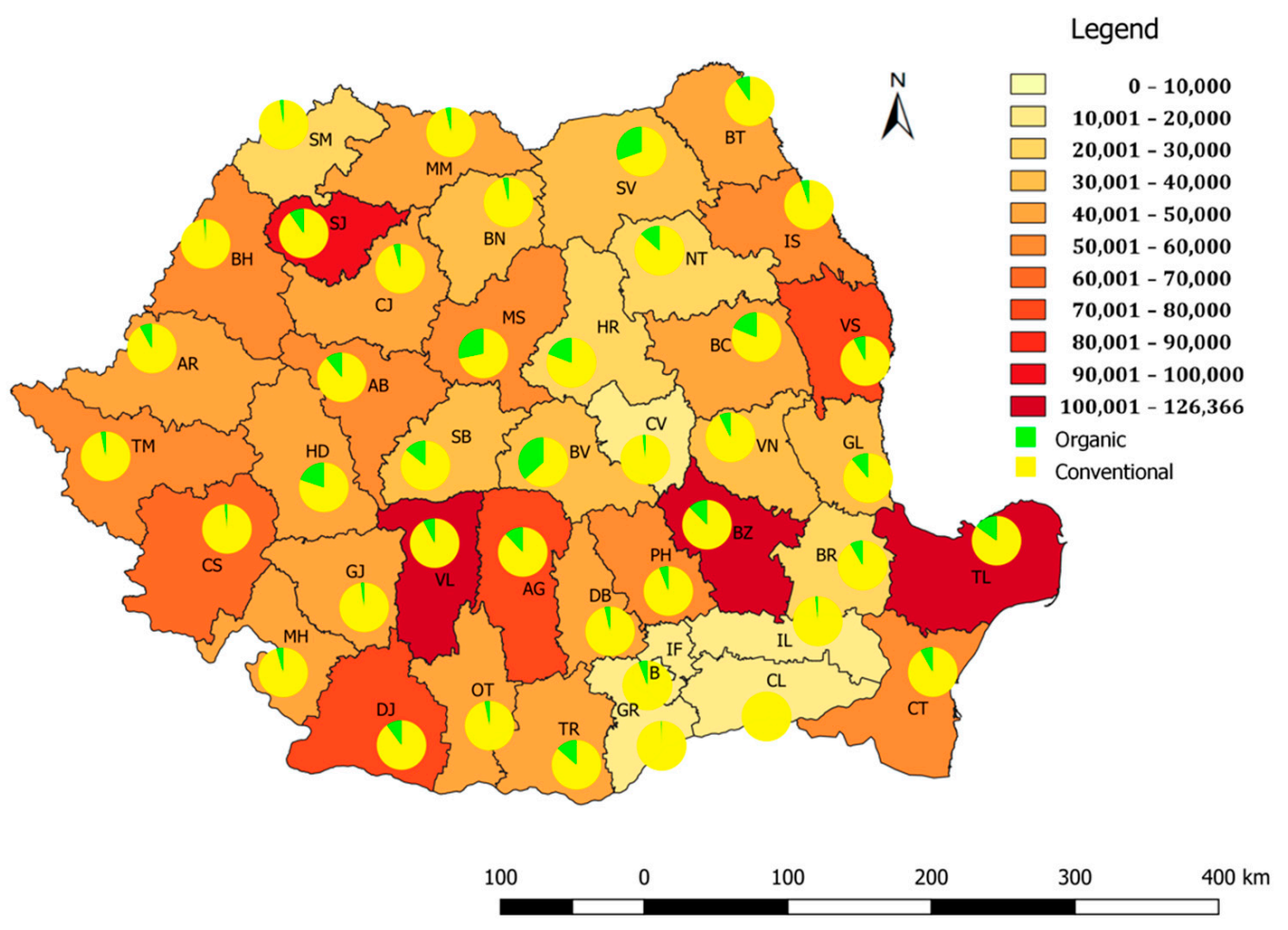

Figure 3. The distribution of beehives in Romania (2019).

A detailed analysis based on making a 5-county top according to four main indicators (total number of beehives, number of beehives in organic system, total number of beekeepers, and number of organically certified beekeepers) highlighted the following features: the Romanian beekeeping system, in terms of beehives, was concentrated (with a percentage of 25.3\%) in the following counties: Vâlcea (VL), Tulcea (TL), Buzău (BZ), Sălaj (SJ), and Dolj (DJ). Also, 34.8\% of the organically certified beehives were in the following counties: Mureș (MS), Tulcea (TL), Buzău (BZ), Brașov (BV), and Suceava (SV). Out of the total number of 25,929 organically certified beekeepers, $24 \%$ were in the counties of Vâlcea (VL), Buzău (BZ), Tulcea (TL), Dolj (DJ), and Sălaj (SJ). While 34.3\% of the organically certified beekeepers were located in 5 counties: Tulcea (TL), Brașov (BV), Mureș (MS), Suceava (SV), and Buzău (BZ).

\subsection{Results Based on Primary Data}

\subsubsection{Study Population}

The demographic data can provide an overall picture of the study population. Compared to the preliminary results of the prior-published article [45], the structure of the sample changed in relation to certain sociodemographic variables (Table 1).

We can safely state that nearly $55 \%$ of the participants to this survey have somewhere between 11 and 80 beehives. This percentage, in most cases, could be related to a family business or a hobby where, in almost $80 \%$ of the cases, one or two members of the same family were involved in running the business, while in $67 \%$ of the cases there were no outsiders. It was an activity that is mainly carried out by men (87.3\%). Beekeeping was quite often run by persons over 35 years old, while only $12.5 \%$ were younger. Another significant feature relied on the fact that beekeeping was generally carried out by graduates of higher education (63\%). Additionally, $38.8 \%$ of the beekeepers who took part in this survey came from a long line of beekeepers, while $53.6 \%$ had been practicing beekeeping for more than 10 years. 
Table 1. Characteristics of the surveyed beekeepers.

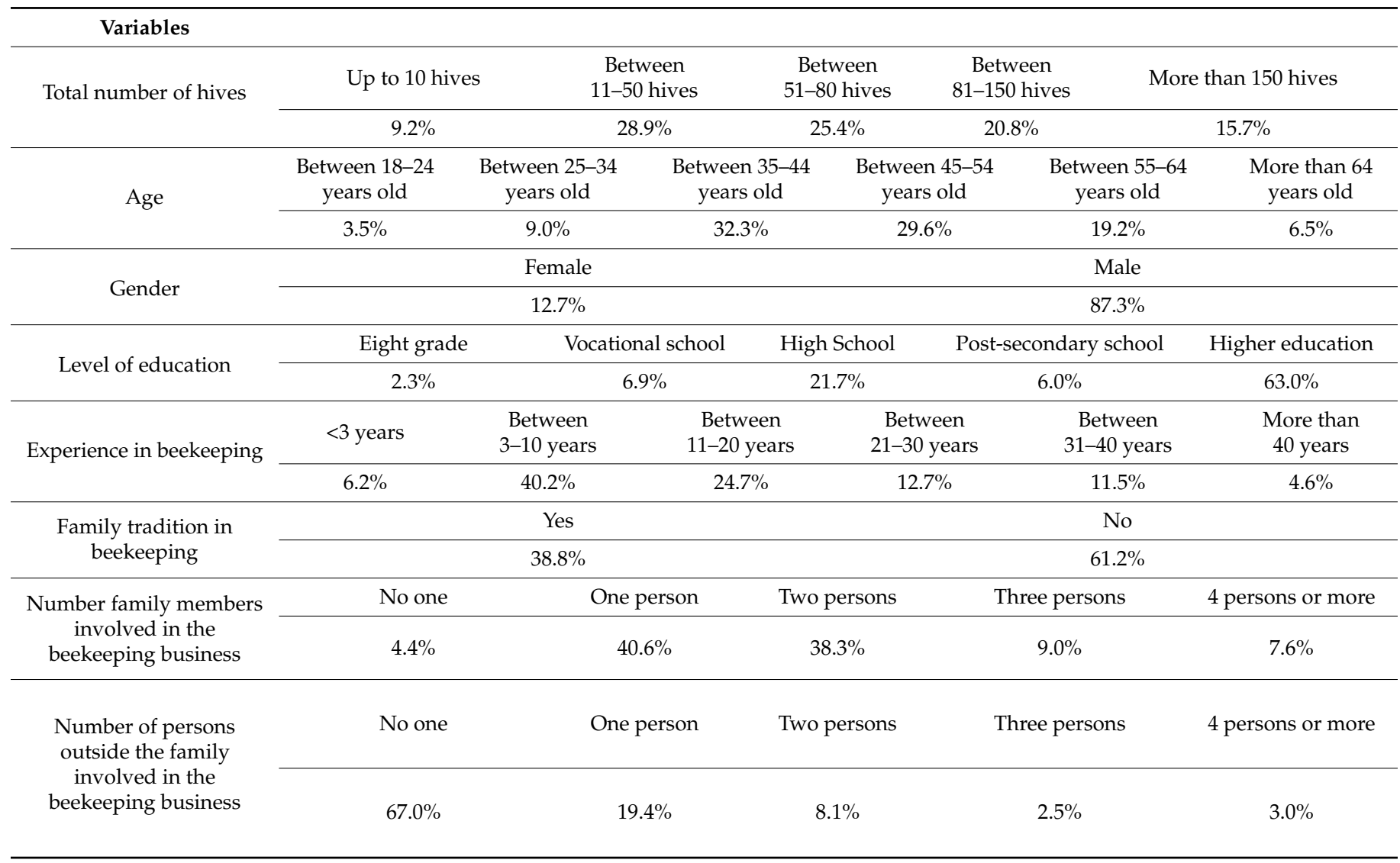

\subsubsection{The Type of Beekeeping Practiced}

Over half of the participants, based on their self-perception, considered that their beekeeping practices were conventional, and nearly $20 \%$ considered that their beekeeping practices were organic. The remaining $24.9 \%$ evaluated themselves practicing a mixed type of beekeeping.

According to another classification, almost $40 \%$ were into stationary beekeeping, $27.9 \%$ ran a migratory beekeeping business, and the other $32.3 \%$ stated they implement a mixed type of beekeeping practices.

In order to examine further relationships among the afore-mentioned categorical variables, MCA was applied. The results showed that beekeepers with less than 3 years experiences tended to be youngest (18-25 years) and had less than 10 hives. On the contrary, beekeepers with the longest experiences (30 years and more) tended to be in the oldest segments (55-64 years, $>64$ years) and manage more than 150 hives. Migratory beekeeping was associated with conventional beekeeping and a higher numbers of beehives (81-150 hives, $>150$ hives), while stationary beekeeping was more associated with a smaller number of hives (11-50 hives) and mixed (organic/conventional) beekeeping or only organic beekeeping (Figure 4). 


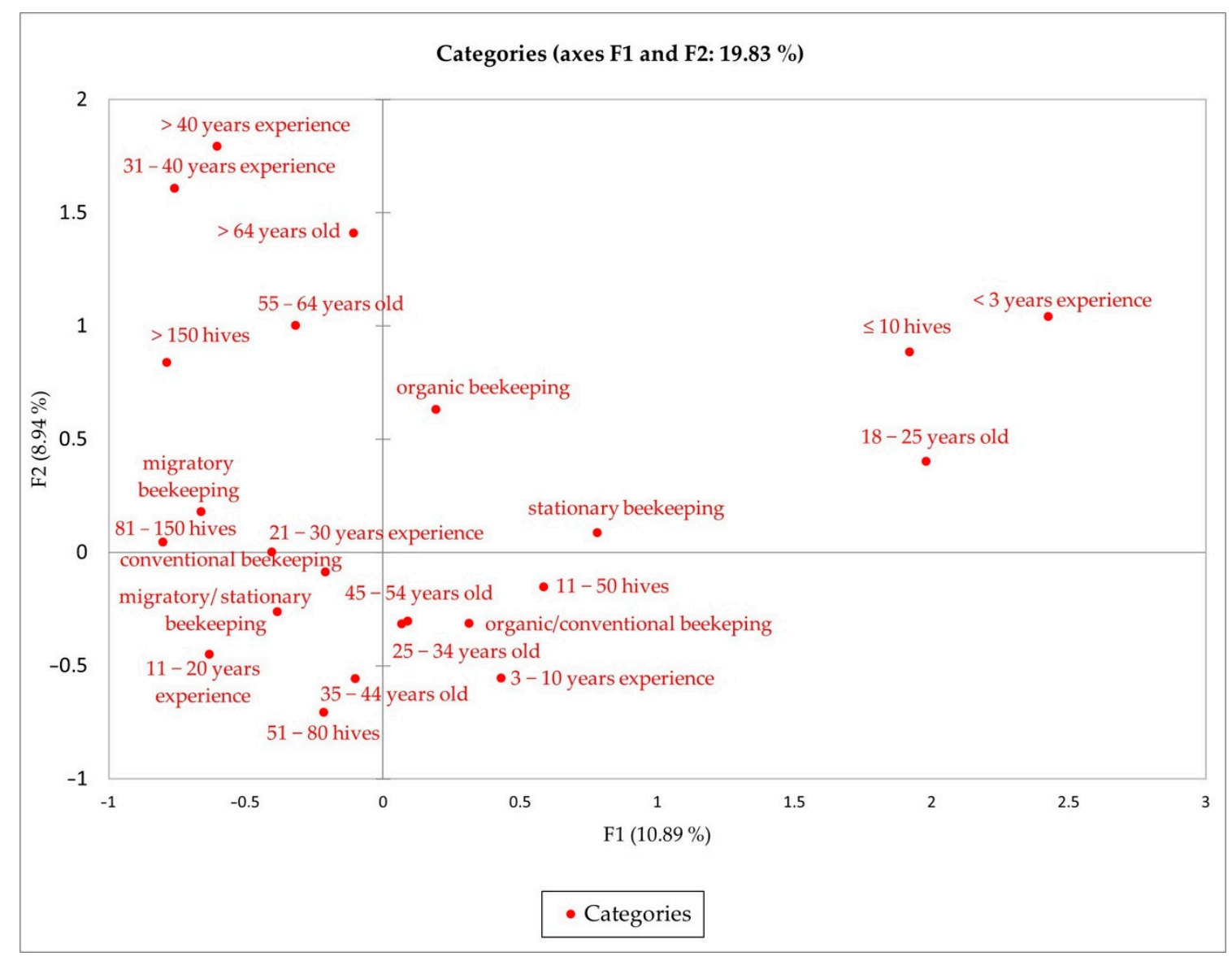

Figure 4. Multiple correspondence analysis (MCA) illustrating two dimensions, created by using the following variables: number of hives, experiences in beekeeping, beekeepers' age, type of beekeeping.

\subsubsection{Organic Beekeeping}

According to the results, $82 \%$ of the beekeepers stated that they were aware of the principles involved in organic beekeeping. When asked to specify some of these principles, the following keywords come into view: treatment, certifications, wax, organic, taxes, honeycomb, yearly, expensive, medicine. Of the respondents, $58.9 \%$ were unaware of the costs involved in practicing organic beekeeping. Moreover, the results of Chi-square test ( $p$-value $<0.0001$ ) showed that majority of beekeepers who did not know the costs in organic beekeeping were in conventional or mixed beekeeping.

A large percentage of respondents, namely $84.1 \%$, thought that organic beekeeping can be beneficial for the environment. Additionally, $92.4 \%$ of the beekeepers thought that creating "ecological beekeeping areas" would be beneficial for both beekeepers and farmers. These areas could be used during the low-flowering season.

We should underline the fact that there was a category of beekeepers who use organic beekeeping practices, without being certified. This statement was in line with our results: the beekeepers who had the organic certification of their apiaries represented merely $9.9 \%$, a percentage that can be further completed by $1.8 \%$ (represented by those partially certificated) and by another $1.4 \%$ (who are presently converting to organic beekeeping).

Out of a series of 5 images/logos, the EU symbol for organic beekeeping was recognized by merely $30.7 \%$ of the beekeepers. In addition, MCA revealed that beekeepers who did not have knowledge about organic principles and apply conventional or mixed type of beekeeping tended to identify wrong EU symbol for organic beekeeping. Moreover, beekeepers who indicated that their beekeeping was organic (fully certified, partially certified, and in conversion) were more associated with knowing organic principles, costs involved in practicing organic beekeeping, as well as they tend to think that organic beekeeping 
can bring benefits to the environment and agree with importance of creating "ecological beekeeping areas" for bees (Figure 5).

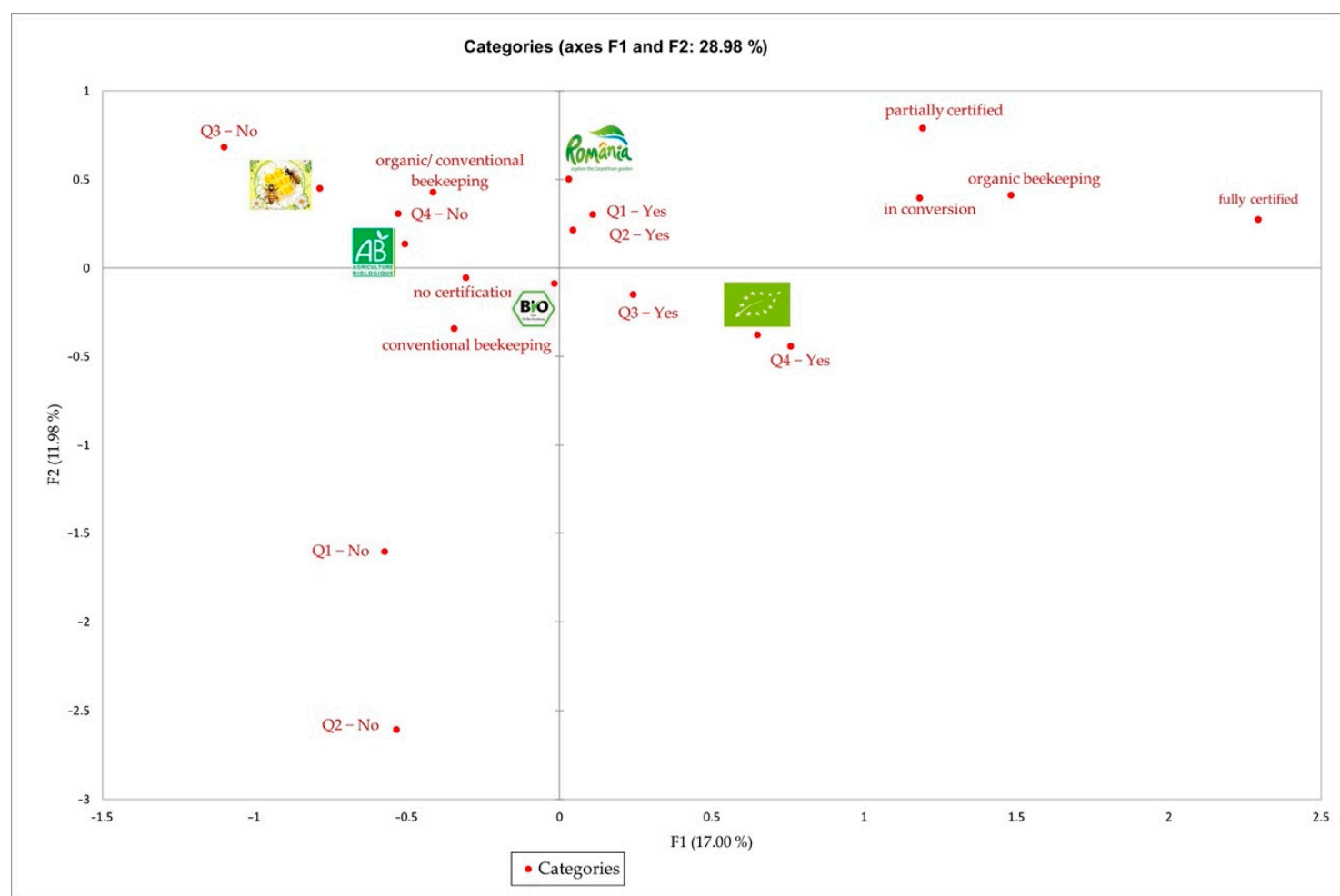

Q1: Do you think that practicing organic beekeeping can bring benefits to the environment? Q2: Do you think it would be useful for beekeepers and farmers to set up "ecological beekeeping areas", which could be used mainly during low-flowering season? Q3: Do you have knowledge about organic principles? Q4: Do you know the costs involved in practicing organic beekeeping?

Figure 5. Multiple correspondence analysis (MCA) illustrating two-dimensional plot (F1 versus F2), created by using the following questions: type of beekeeping, logo of organic beekeeping, benefits of organic beekeeping for the environment, interest for "ecological beekeeping areas", knowledge about organic principles, and costs involved in practicing organic beekeeping. Each question represented either binary variable with a yes/no response or variable with a multiple responses.

\subsubsection{Sustainable Development of Beekeeping}

The concept of sustainable development was known by $71.6 \%$ of the beekeepers who further evaluated the importance of three components of sustainability in beekeeping (environmental, economic, and social component). By applying the Friedman test, significant differences in evaluation of components were confirmed ( $p$-value $\leq 0.0001)$. Multiple pairwise comparisons using Nemenyi's procedure were applied in order to examine among which components there were significant differences (Table 2). Based on descriptive statistics, it can be stated that $83.8 \%$ considered the environmental pillar as a very important feature of the beekeeping sustainability. The economic component was also viewed as very important by $61.6 \%$, while the social component was significant for $41.7 \%$ of them. Interesting results were obtained by MCA, which examined association between number of hives, knowledge about organic principles, and awareness of the sustainability concept in beekeeping. Based on the results (Figure 6), it can be stated that beekeepers with a higher number of hives were more aware about the concept of sustainability in beekeeping as well as about organic principles. 
Table 2. Results of pairwise comparisons (Nemenyi's procedure) illustrating significant differences in assessing the importance of the selected components in sustainability.

\begin{tabular}{ccccc}
\hline Sample & Mean of Ranks & \multicolumn{2}{c}{ Groups } \\
\hline social & 1.640 & A & & \\
economic & 2.040 & & B & $\mathrm{C}$ \\
environmental & 2.319 & & \\
\hline
\end{tabular}

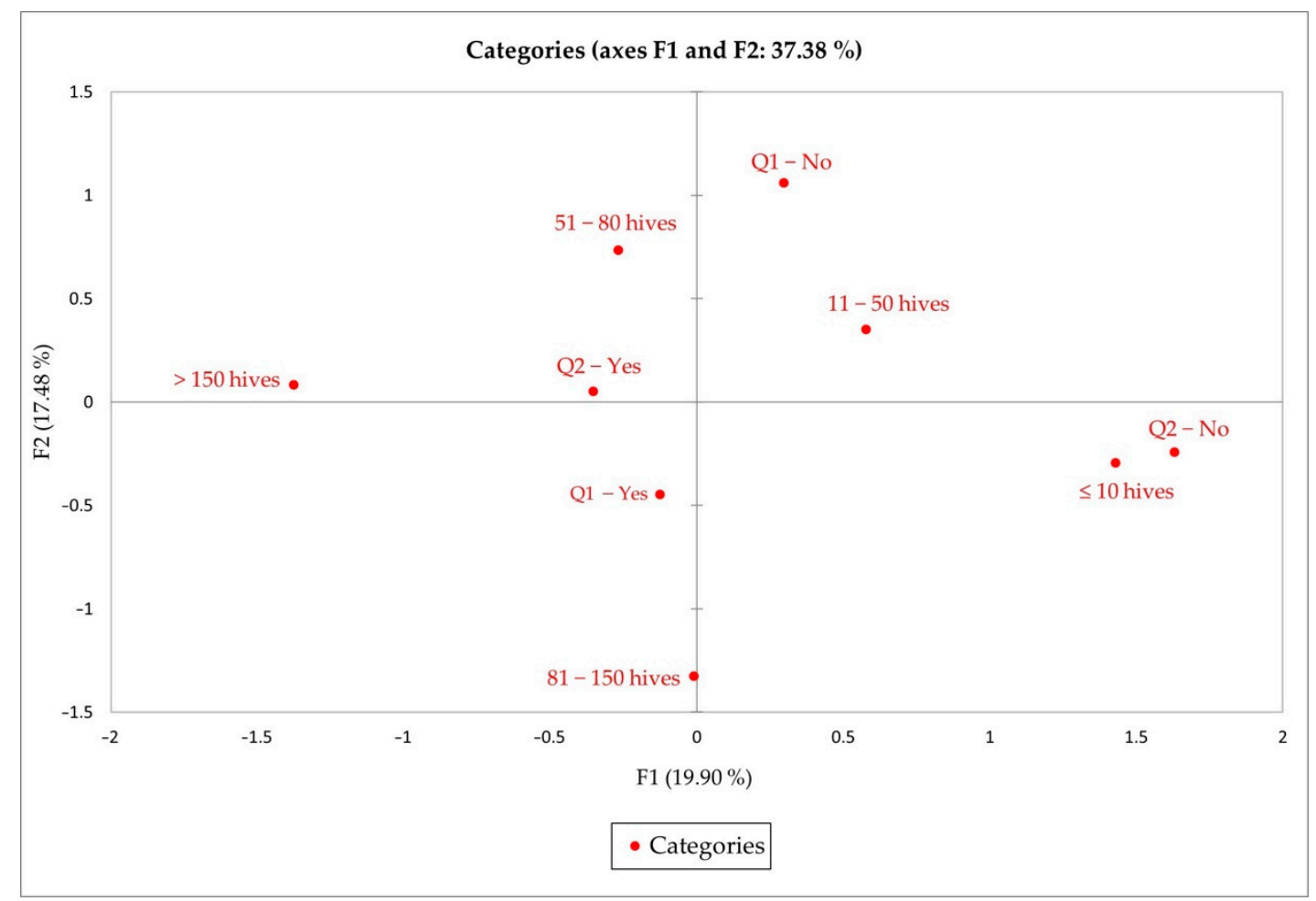

Q1: Have you heard about the concept of sustainable beekeeping development? Q2: Do you have knowledge about organic principles?

Figure 6. Multiple correspondence analysis (MCA) illustrating two-dimensional plot (F1 versus F2), created by using the following questions: number of hives, awareness about the concept of sustainable beekeeping, and knowledge about organic principles. Each question represented either binary variable with a yes/no response or variable with a multiple responses.

Concerning the economic pillar of sustainability, we analyzed the main products obtained and the main distribution channels used by beekeepers. Out of all bee products, honey was produced by almost all beekeepers $(98.1 \%)$. Wax was obtained by $76.3 \%$ of the beekeepers, $64 \%$ of them also produced propolis, $48.3 \%$ obtained pollen, a significantly smaller percentage $(7.7 \%)$ produced royal jelly, and merely $0.5 \%$ of the beekeepers obtained bee venom. Other bee products were honey cappings, bee bread, honeycomb, queen bees, and bee colonies. Among those who have declared they obtained honey, $81 \%$ stated they produced polyfloral honey. The sunflower honey (47.9\%) and acacia honey $(46.7 \%)$ got close results in terms of production, while the rapeseed honey $(34.8 \%)$ and linden honey $(32.9 \%)$ shared lower percentages. The rarest type of honey was the honeydew honey, produced by $14.2 \%$ of the respondents. Other spontaneous mentions included mint, coriander, and blue eryngo honey as well. Of the beekeepers, $43.9 \%$ declared that they had produced, at least one time, honey with various additions, such as pollen, propolis, dried fruit, or seeds.

The majority of beekeepers commercialized the honey obtained through some acquaintances and friends (that was the case of $90.2 \%$ of them). Of the beekeepers, $29.2 \%$ stated they sell it wholesale to certain intermediary parties, $15.2 \%$ sell it online, and nearly 
$11.7 \%$ sell in farmers' markets. The large retail chains were hardly accessible to most of them, as merely $0.5 \%$ of the beekeepers had managed to sell through them.

\subsubsection{Effects of Pandemic Crisis on Beekeeping in Romania}

The pandemic crisis triggered by COVID-19 affected 30.3\% of the beekeepers. Since most of them sell their bee products through direct interaction (friends, relatives, acquaintances, markets, fairs, etc.), the drop in sales was the most common negative effect along with the travel restrictions to certain sale points: "Closed restaurants, few or no orders. From March to May 2020, the quarantine meant that people used to go out for essential stuff, so honey sales registered a decrease of $90 \% "$. The travel restrictions also affected the access to apiaries, and numerous beekeepers mentioned in the open answers that they could not properly check the condition of their beehives: "In the spring of 2020, due to the imposed restrictions, we did not stimulate/fed the bees for a proper development".

Since there is a high percentage of beekeepers who continue to practice migratory beekeeping, the travel limitations severely impacted their results this year: "The restriction or subjecting the migratory travelling, along with a bigger bureaucracy for obtaining travel permits"; "I went late on the migratory travel. I missed two harvests!". Other situations mentioned were the lack of options in the case of networking and experience exchange with other beekeepers, as well as seasonal workforce shortages or the drop in buying power.

However, there was still a significant number of beekeepers who declared there were also some positive aspects of this crisis, and they generally registered an increase of the orders and a demand for a higher-quality honey, and some were even able to raise the prices: "The price of honey has increased and so has the interest towards it", "The demand for high-quality products has increased and there is no offer".

\section{Discussion}

The portrayal of the beekeeping situation in Romania—by employing primary and secondary statistical data-aimed at introducing the main beekeeping practices currently used by the Romanian beekeepers, as well as their problems during the present crisis triggered by the pandemic. Supporting the adoption of sustainable beekeeping practices, mainly organic practices should start with the illustration of the beekeeping sector situation and its potential. The same idea was expressed in the research conducted by Gomes et al. [31] in Portugal, who believed that getting data from beekeepers based on inquiries lies at the foundation of presenting the real situation of the beekeeping sector, and that the beekeepers involved in organic beekeeping can become models of good practices for those under conversion or in the early stages of the certification process.

Research conducted in Romania in 2011 revealed that $77 \%$ of the beekeepers considered (based on self-assessment) that they were engaged in conventional beekeeping [46]. The results of the present research showed a smaller percentage, namely $55 \%$ of the beekeepers fell under this category, while the remaining percentage represented the beekeepers involved in organic or mixed beekeeping. This revealed a positive evolution of the beekeeping sector in Romania over the last decade, and also showed that beekeepers were more and more focused on sustainable practices either to address the needs of the consumers or to comply with the public policies supporting the beekeeping sector [47].

The development of organic agriculture, in the case of the former communist countries, was a slow and difficult process due to the lack of support from institutions and civil society [48]. Romania went through the same stages in the 90s, affected by the mistrust and negative experiences inherited from the communist period. In the following years, due to the liberalization of the markets and emergence of a proper institutionalized framework, the organic sector started to grow to the benefit of both consumers and producers $[49,50]$. The Romanian beekeeping sector relatively followed the same trend as more and more beekeepers were interested in the principles of organic beekeeping, even if only a small percentage of them were certified. Similar results were shown by Dirimanova and Stoeva [51] regarding the situation of organic beekeeping in Bulgaria, 
which is considered a new sector-too small in reference to the existing results, yet having a significant growth potential. Not only the former communist countries are insufficiently developed in terms of organic beekeeping. For instance, if in Romania the percentage of certified apiaries ranges between 9.9\% (according to the results of the survey) and 5.2\% (according to the secondary statistical data provided by the Ministry of Agriculture and Rural Development) [38], Portugal faces similar challenges, in the sense that merely 5.8\% of the beekeepers were organically certified even if the soil, climate, and environmental conditions are most favorable. Italy enjoys a much better situation as the percentage of organically certified beekeepers was higher, namely $8 \%$ [31]. The correct acknowledgement of the logo for EU organic apiculture by the beekeepers is a key feature, which shows the level of knowledge about the basic principles of organic apiculture. Only a third of the participants to this survey correctly identified this logo, which reveals a lower degree of engagement in marketing their own products. Correct labelling is another significant feature of the marketing mix, and Romanian beekeepers need to get more involved in creating added value and promoting their products.

Similar results were reported by Lyubenov et al. [52], which stated that, by comparison with other traders, beekeepers were generally less engaged in marketing activities and therefore they should create their own markets since organic bee products are a perfect fit for the digital marketing.

Acknowledging the concept of sustainable development is also a key element for beekeepers. Most participants to this study had heard of the concept of sustainability, paying special attention to the environmental problems, followed by the economic and social problems. The fact that the term of «sustainability» had become a familiar word in agribusiness, in general, and particularly in beekeeping, was confirmed by other researchers too $[11,53]$. We can see that the social aspects had little weight among the Romanian beekeepers who took part in this study. It is our belief that the elements linked to the social pillar of sustainability should be given a broader publicity among beekeepers as they represent the link that helps develop all other elements, namely the economic and environmental elements. Similar results were found in studies conducted in transition countries such as Ukraine which put a greater emphasis on the social role of beekeeping, including its importance for rural development [54].

The challenges faced by beekeepers in 2020 caused by the pandemic, were partly related to the management of the apiary, and to the economic efficiency as well. The restrictions imposed on travel limited the access to the apiaries and impeded the necessary treatments or other activities, which could not be completed in due time. The same problems were reported by Özkirim [55] regarding the impact of COVID-19 on beekeeping in Turkey. Thus, beekeepers were unable to run their usual activities according to a schedule (sanitizing the beehives, treatments against Varroa, and feeding the bees). If, in Romania, beekeepers complained about the lack of social interaction and experience exchanges with their fellow beekeepers, in Turkey, the beekeepers over 65 years old were helped by neighbors or younger colleagues to take care of their bees [55]. The beekeepers involved in migratory beekeeping were also affected by the travel limitations enforced in the spring of 2020 and therefore missed several honey harvests.

Corresponding results were signaled by Özkirim [55]. If, in economic terms, the beekeepers were affected in the first months of the pandemic (March-May 2020) by the sales drop, there were also some positive effects of the sanitary crisis, such as a greater demand for high-quality honey. The consumer's acknowledgement of the benefits brought by certified bee products, local products, importance of the individual and collective health, and the necessity to protect the environment during the pandemic were also highlighted by Giménez-Candela [56]. The positive effects of the pandemic crisis on the beekeeping activity were observed in Germany, where beekeepers sold more honey during the pandemic than before. The main reasons for the increase of honey sales were related to consumer awareness for regional high-quality products, but also to their eating habits and their preferences for short supply chains [57]. 
Another challenge faced by organic beekeepers was linked to issues related to plant protection products and residues in bee products and bees. According to Mitchell et al. [58], residues of neonicotinoids were detected in a variety of honey samples all over the world. Moreover, application of plant protection products in both urban and rural areas can lead to bee products' contamination $[59,60]$. Several contaminations by glyphosate were reported in Germany and one organic beekeeper had to destroy a significant amount of honey due to the exceeding the maximum residue levels of glyphosate [61]. The residues from glyphosate are not usually the part of bee products analyses due to high analytical costs or due to the lack of methods [62]. Bee products' contamination may threaten the future of many beekeepers; however, organic beekeeping can bring certain benefits in case of these residues. Furthermore, organic beekeeping can solve the problems with residues from chemical treatments against Varroa, mainly from application of acaricides, which can create residues in bee products $[59,63]$.

In Romania, the beekeeping sector has made remarkable achievements over the last decades in terms of sustainability, but the percentage of beekeepers who practice organic beekeeping is still low compared to other European Union member states. The National Beekeeping Programs provided financial support to beekeepers in order to improve the quality of products obtained, with a view to better valorize the potential of bee products on the national and international markets [64]. The positive effects of the National Beekeeping Programs implemented in Romania during 2008-2020 were proven by the increase in the number of beehives. The support measures varied between different programming periods, depending on the needs of each country. For example, in 2019, there were two measures eligible for funding dedicated to organic beekeeping: "combating beehive invaders and diseases, particularly varroosis" and "restocking of beehives-funding activities to promote queen production, purchasing of bee colonies or buying new hives" [65]. The expected social impact of the current Romanian National Beekeeping Program (2020-2022) [66] was also related to the undertaking of organic beekeeping practices and the certification of bee products. This was a consequence of the retrospective analysis made for the previous years in terms of the effects of support measures. Furthermore, there was an increasing interest for organic certification in Romania among beekeepers, due to the gap between the price of organic and conventional honey [67]. According to existing regulations in Europe, organic honey had the major advantage of a certified quality guarantee. If the conventional honey market is shaken by scandals regarding its falsity, the organic one benefits from a better traceability [67]. In this context, the conversion from conventional to organic beekeeping systems will provide benefits for Romanian beekeepers in terms of earning higher incomes and of practicing an honest and uncompromising activity. As a consequence, beekeepers who practice organic beekeeping and are successful with their business could be an example for many others. Using the good practices in organic beekeeping is a real challenge that can have a multiplication effect among beekeepers. The authors recommend better policies that can help address this challenge. Designing effective and coherent policies for organic beekeeping in Romania should start from the "real picture" of the sector provided by scientists and continue with the creation of synergies between all stakeholders involved in the beekeeping chain. The critical issue is to connect these actors and to create sustainable production and consumption systems in beekeeping.

The limitation of the study is related to some methodological aspects: the beekeepers involved in the study selected themselves into the sample. The online survey was the only possibility to collect primary data, due to the pandemic crisis and to the sanitary and travel restrictions. These limitations were compensated by the increased popularity of the internet among beekeepers and many professional groups, as beekeepers' associations are present in social media. The advantages of online survey research were also confirmed by Wright [68]. 


\section{Conclusions}

The purpose of the present study was to create a "real picture" of the Romanian beekeeping sector and to map the position of organic beekeeping among Romanian beekeepers. The results showed that organic beekeeping was practiced in Romania by $5.2 \%$ of beekeepers and $9.7 \%$ of hives were in an organic system. The majority of surveyed beekeepers were aware of the organic principles and considered organic beekeeping and the creation of "ecological beekeeping areas" to be beneficial for the environment, beekeepers, and farmers. Stationary beekeeping was more associated with organic beekeeping and a fewer number of bees (11-50 hives).

The concept of sustainable development was known mostly among beekeepers who had a higher number of hives and were aware of organic principles in beekeeping. The importance of components in sustainability was identified as follows: environmental > economic > social. According to $30 \%$ of surveyed beekeepers, the pandemic crisis triggered by COVID-19 had an impact on the above-mentioned aspects: environmental-the decrease of bees' welfare due to the improper management of the beehive (as a consequence of the transport restrictions for beekeepers); the decrease of pollination services; economic-the decrease of profitability (decrease of sales), increasing demand for bee products as healthy food; social-the lack of social interactions between beekeepers (sharing experiences and good practices, training activities).

Our findings showed the great development potential of organic beekeeping in Romania. This was determined by the huge awareness of sustainability aspects and by the positive attitude of beekeepers towards organic principles. Based on these results, beekeepers should be encouraged and supported to follow the organic certification procedures in order to obtain high-quality products. This will be beneficial for producers, consumers, and the environment.

Author Contributions: The present paper was conceived and designed by C.B.P. Conceptualization, C.B.P. and P.Š.; introduction, C.B.P., P.Š. and I.S.B.; methodology, C.B.P., A.C., P.Š. and I.S.B.; results and discussion, C.B.P., A.A., P.S.S. and I.S.B.; statistical analysis and interpretation, A.A., P.Š., I.S.B. and C.B.P.; editing, C.B.P., P.Š., I.S.B. and A.C. All authors have read and agreed to the published version of the manuscript.

Funding: The study was conducted under a project entitled «Développement durable de l'apiculture: enjeux économiques, écologiques, de développement rural et de santé publique», 2019-2021, financed by "L'Agence Universitaire de la Francophonie en Europe Centrale et Orientale".

Acknowledgments: Thanks go to Sonia Bulei for the English translation. We would like to thank our reviewers for the suggestions that led to improving this material.

Conflicts of Interest: The authors declare no conflict of interest.

\section{References}

1. Kritsky, G. Beekeeping from antiquity through the middle ages. Annu. Rev. Entomol. 2017, 62, 249-264. [CrossRef]

2. Crane, E. A short history of knowledge about honey bees (Apis) up to 1800. Bee World 2004, 85, 6-11. [CrossRef]

3. Francis-Baker, T. Bees and Beekeeping; Bloomsbury Publishing: London, UK, 2021.

4. Martinello, M.; Mutinelli, F. Antioxidant activity in bee products: A review. Antioxidants 2021, 10, 71. [CrossRef] [PubMed]

5. Vrabcová, P.; Hájek, M. The economic value of the ecosystem services of beekeeping in the Czech Republic. Sustainability 2020, 12, 10179. [CrossRef]

6. Veland, R.; Hisrich, R.D.; Leo-Paul, D.; Ramo, P.; Laxman, P. Beekeeping as a family artisan entrepreneurship business. Int. J. Entrep. Behav. Res. 2019, 25, 717-730. [CrossRef]

7. Hinton, J.; Schouten, C.; Austin, A.; Lloyd, D. An overview of rural development and small-scale beekeeping in Fiji. Bee World 2020, 97, 39-44. [CrossRef]

8. Altunel, T.; Olmez, B. Beekeeping as a rural development alternative in turkish northwest. Appl. Ecol. Environ. Res. 2019, 17, 6017-6029. [CrossRef]

9. Vinci, G.; Rapa, M.; Roscioli, F. Sustainable development in rural areas of mexico through beekeeping. Int. J. Sci. Eng. Invent. 2018, 4, 1-7. [CrossRef]

10. Pocol, C.B.; McDonough, M. Women, apiculture and development: Evaluating the impact of a beekeeping project on rural women's livelihoods. Bull. Univ. Agric. Sci. Vet. Med. Cluj Napoca Hortic. 2015, 72. [CrossRef] 
11. Panta, N.D. Applying value chain analysis through the lens of sustainability to enterprises in the beekeeping sector. LUMEN Proc. 2020, 11. [CrossRef]

12. Patel, V.; Pauli, N.; Biggs, E.; Barbour, L.; Boruff, B. Why bees are critical for achieving sustainable development. Ambio 2021, 50, 49-59. [CrossRef] [PubMed]

13. Gaviglio, A.; Bertocchi, M.; Demartini, E. A tool for the sustainability assessment of farms: Selection, adaptation and use of indicators for an italian case study. Resources 2017, 6, 60. [CrossRef]

14. Kádeková, Z.; Savov, R.; Košičiarová, I.; Valaskova, K. CSR activities and their impact on brand value in food enterprises in Slovakia based on foreign participation. Sustainability 2020, 12, 4856. [CrossRef]

15. Porsche, H.; Fischer, M.; Braga, F.; Häni, F. Introduction of the Sustainability Assessment Tool RISE into Canadian Agriculture; Swiss College of Agriculture: Zollikofen, Switzerland, 2013.

16. Talukder, B.; Blay-Palmer, A. Comparison of Methods to Assess Agricultural Sustainability BT—Sustainable Agriculture Reviews; Lichtfouse, E., Ed.; Springer International Publishing: Cham, Switzerland, 2017. [CrossRef]

17. Rahimi, M.K.; Abbasi, E.; Bijani, M.; Tahmasbi, G.; Azimi Dezfouli, A.A. Sustainability criteria of apicultural industry: Evidence from Iran. Ecosyst. Health Sustain. 2020, 6. [CrossRef]

18. Kouchner, C.; Ferrus, C.; Blanchard, S.; Decourtye, A.; Basso, B.; Le Conte, Y.; Tchamitchian, M. Sustainability of beekeeping farms: Development of an assessment framework through participatory research. In Proceedings of the 13th European International Farming Systems Association (IFSA) Symposium, Farming Systems: Facing Uncertainties and Enhancing Opportunities, Crete, Greece, 1-5 July 2018; pp. 1-14.

19. Kouchner, C.; Ferrus, C.; Blanchard, S.; Decourtye, A.; Basso, B.; Le Conte, Y.; Tchamitchian, M. Bee farming system sustainability: An assessment framework in metropolitan France. Agric. Syst. 2019, 176, 102653. [CrossRef]

20. Juríčková, Z.; Lušňáková, Z.; Hallová, M.; Horská, E.; Hudáková, M. Environmental impacts and attitudes of agricultural enterprises for environmental protection and sustainable development. Agriculture 2020, 10, 440. [CrossRef]

21. Bekena, N.; Greiling, J. Quality focused apiculture sector value chain development in Ethiopia. J. Agric. Sci. Technol. A 2017, 7, 107-116. [CrossRef]

22. Castelló, E. Storytelling in applications for the EU quality schemes for agricultural products and foodstuffs: Place, origin and tradition. Spanish J. Agric. Res. 2020, 18, 1-12. [CrossRef]

23. Melece, L.; Shena, I. Organic beekeeping development in Latvia. In Proceedings of the X International Agriculture Symposium, "Agrosym 2019", Jahorina, Bosnia and Herzegovina, 3-6 October 2019; pp. 1151-1157.

24. Gomes, T.; Feás, X.; Iglesias, A.; Estevinho, L.M. Study of organic honey from the northeast portugal. Molecules 2011, 16, 5374-5386. [CrossRef]

25. Silva, S.; Oliveira, E.R.; Pereira, T.L.; Carbonari, V.; Muniz, E.B.; Menegat, A.S.; Gabriel, A.; Nunes, F.; da Silva, A.L.; de Lima, J.C.; et al. Beekeeping: Organic and agroecological system of breeding of bees in areias settlement-High pantanal. Realizacao 2019, 6, 14-25. [CrossRef]

26. Dupleix, A.; Bruneau, E.; Bröker, U.; Chlebo, R.; Garibay, S. MINIPAPER 03: Taking into Account the Well-Being of Bees in Production: Developing Husbandry Staying as Close as Possible to the Natural Living Conditions of Bees While Being Productive. 2020. Available online: https:/ / ec.europa.eu/eip/agriculture/sites/default/files/fg34_mp3_considering_well_being_bees_ final.pdf?fbclid=IwAR1ou7gUUe2xXq9Drqm0AdJSpj5Iw4DaLe9mNFnOC0vWVxTScqcjxlx70uc (accessed on 20 June 2020).

27. European Comision. Council Regulation (EC) No 834/2007 of 28 June 2007 on Organic Production and Labelling of Organic Products and Repealing Regulation (EEC) No 2092/91. 2007. Available online: https:/ / eur-lex.europa.eu/legal-content/EN/ TXT/?uri=celex\%3A32007R0834 (accessed on 20 June 2020).

28. European Comision. Commission Regulation (EC) No 889/2008 of 5 September 2008 Laying down Detailed Rules for the Implementation of Council Regulation (EC) No 834/2007 on Organic Production and Labelling of Organic Products with Regard to Organic Production, Labelling and Co. 2008. Available online: https://eur-lex.europa.eu/legal-content/EN/TXT/?uri= CELEX\%3A32008R0889 (accessed on 20 June 2020).

29. EIP-AGRI. Bee Health and Sustainable Beekeeping: Final Report. 2020. Available online: https:/ / ec.europa.eu/eip/agriculture/ en/focus-groups/bee-health-and-sustainable-beekeeping (accessed on 22 March 2021).

30. The World Of Organic Agriculture-Statistics and Emerging Trends 2020; Willer, H.; Schlatter, B.; Trávnícek, J.; Kemper, L.; Julia, L. (Eds.) Research Institute of Organic Agriculture (FiBL): Frick, Switzerland; IFOAM-Organic International: Bonn, Germany, 2020.

31. Gomes, M.; Casaca, J.; Cabo, P.; Dias, L.G.; Vilas-Boas, M. Trade barriers and economic impact of organic beekeeping in Portugal. In Book of Abstracts of the II International Symposium on Bee Products-Annual Meeting of the International Honey Commission; Instituto Politécnico de Bragança: Bragança, Portugal, 2012; pp. 115-116.

32. Güemes-Ricalde, F.J.; Villanueva-G, R.; Echazarreta-González, C.; Gómez-Alvarez, R.; Pat-Fernández, J.M. Production costs of conventional and organic honey in the Yucatán peninsula of Mexico. J. Apic. Res. 2006, 45, 106-111. [CrossRef]

33. Thrasyvoulou, A.; Broeker, U.; Chrysoula, T.; Vilas-Boas, M.; Wallner, K.; Amsler, T.; Garces, S.; Lodesani, M.; Siceanu, A.; Westerhoff, A.; et al. Improvements to the regulations on organic farming to facilitate the practice of organic beekeeping. Bee World 2014, 91, 58-61. [CrossRef]

34. Bodescu, D. Economia Apicolă în Județele Iași și Neamț; Terra Nostra Iași: Iași, Romania, 2007; ISBN 978-973-8432-71-0. 
35. INS. AGR201A—Livestock, by Animal Category, Ownership form, Macroregions, Development Regions and Counties, at the End of Year. Available online: http://statistici.insse.ro:8077/tempo-online/\#/pages/tables/insse-table (accessed on 15 December 2020).

36. Năstase, I.P.; Toader, M.; Șonea, C. Study on legislation of organic products quality. Lucr. Ştiinţifice Ser. Agron. USAMV București 2018, 61, 151-156.

37. Rivera-Gomis, J.; Bubnic, J.; Ribarits, A.; Moosbeckhofer, R.; Alber, O.; Kozmus, P.; Jannoni-Sebastianini, R.; Haefeker, W.; Köglberger, H.; Smodis Skerl, M.I.; et al. Good farming practices in apiculture. Rev. Sci. Tech. 2019, 38, 879-890. [CrossRef]

38. MADR. Agricultura Ecologică în România. 2020. Available online: https:// www.madr.ro/agricultura-ecologica.html (accessed on 22 March 2021).

39. Agrebi, E.; Steinhauer, N.; De Graaf, D. Beekeeper's perception of risks affecting colony mortality: A pilot survey. Authorea Prepr. 2020, 1-15. [CrossRef]

40. Lupo, C.; Wilmart, O.; Van Huffel, X.; Dal Pozzo, F.; Saegerman, C. Stakeholders' perceptions, attitudes and practices towards risk prevention in the food chain. Food Control 2016, 66, 158-165. [CrossRef]

41. Bodescu, D.; Ștefan, G.; Pânzaru, R.L.; Moraru, R. Perception of the beekeepers regarding the principles of sustainable development in the north-eastern region of Romania. Sci. Pap. Ser. Manag. Econ. Eng. Agric. Rural Dev. 2019, 19, 77-84.

42. QGIS 3.16.0 "Hannover". Available online: https:/ / www.qgis.org/en/site/ (accessed on 15 December 2020).

43. Hacer, C.A.; Melike, C. Effects of socio-economic factors on the consumption of milk, yoghurt, and cheese: Insights from Turkey. Br. Food J. 2010, 112, 234-250. [CrossRef]

44. Horská, E.; Petril'ák, M.; Šedík, P.; Nagyová, L'. Factors influencing the sale of local products through short supply chains: A case of family dairy farms in Slovakia. Sustainability 2020, 12, 8499. [CrossRef]

45. Pocol, C.B.; Brumă, I.S. L'apiculture Roumaine-Enjeux et solutions pour l'avenir. In Communication, Environnement et Development Durable. Études de Cas; Presa Universitară Clujeană: Cluj Napoca, Romania, 2021. [CrossRef]

46. Pocol, C.B. Resources and models of beekeeping exploitations in the North West region of Romania. Bull. Univ. Agric. Sci. Vet. Med. Cluj Napoca Hortic. 2011, 68, 180-187. [CrossRef]

47. Majewski, J. Beekeeping support in the European Union countries. Sci. Pap. Ser. Manag. Econ. Eng. Agric. Rural Dev. 2017, 17, 193-197.

48. Zagata, L.; Hrabák, J.; Lošt'ák, M. Post-socialist transition as a driving force of the sustainable agriculture: A case study from the Czech Republic. Agroecol. Sustain. Food Syst. 2020, 44, 238-257. [CrossRef]

49. Nagy, I.D.; Dabija, D.-C. The transition from natural/traditional goods to organic products in an emerging market. Information 2020, 11, 227. [CrossRef]

50. Butu, A.; Vasiliu, C.D.; Rodino, S.; Brumă, I.-S.; Tanasă, L.; Butu, M. The Anthropological analysis of the key determinants on the purchase decision taken by the romanian consumers regarding the ecological agroalimentary products. Sustainability 2019, 11, 4897. [CrossRef]

51. Dirimanova, V.; Stoeva, T. Development of ecological beekeeping in Bulgaria: Status and prospects. Sci. Pap. Ser. Manag. Econ. Eng. Agric. Rural Dev. Econ. Eng. Agric. Rural Dev. 2020, 20, 147-152.

52. Lyubenov, L.; Atanasov, A.; Hristakov, I. Building up own markets for organic bee products. In Proceedings of the International Symposium, ISB-INMA TEH' 2018, Agricultural and Mechanical Engineering, Bucharest, Romania, 1-3 November 2018; pp. 701-706.

53. Friedrich, N.; Heyder, M.; Theuvsen, L. Sustainability management in agribusiness: Challenges, concepts, responsibilities and performance. Proc. Food Syst. Dyn. 2012, 530-546. [CrossRef]

54. Fedoriak, M.; Kulmanov, O.; Zhuk, A.; Shkrobanets, O.; Tymchuk, K.; Moskalyk, G.; Olendr, T.; Yamelynets, T.; Angelstam, P. Stakeholders' views on sustaining honey bee health and beekeeping: The roles of ecological and social system drivers. Landsc. Ecol. 2021. [CrossRef]

55. Özkirim, A. National and global impact of COVID-19 on beekeeping. Mellifera 2020, 20, 1-2.

56. Giménez-Candela, M. Bees and Covid-19: A necessary legal regulation. Derecho Anim. 2020, 11, 9-19. [CrossRef]

57. Ticker Zu Corona: Darf Ich Weiterhin Zu Meinen Bienen? BienenEnatur. 5 April 2020. Available online: https://www. bienenundnatur.de/aktuelles/corona-darf-ich-als-imker-zu-meinen-bienen/ (accessed on 12 March 2021).

58. Mitchell, E.A.D.; Mulhauser, B.; Mulot, M.; Mutabazi, A.; Glauser, G.; Aebi, A. A worldwide survey of neonicotinoids in honey. Science 2017, 358, 109-111. [CrossRef]

59. El Agrebi, N.; Traynor, K.; Wilmart, O.; Tosi, S.; Leinartz, L.; Danneels, E.; de Graaf, D.C.; Saegerman, C. Pesticide and veterinary drug residues in belgian beeswax: Occurrence, toxicity, and risk to honey bees. Sci. Total Environ. 2020, 745, 141036. [CrossRef]

60. Friedle, C.; Wallner, K.; Rosenkranz, P.; Martens, D.; Vetter, W. Pesticide residues in daily bee pollen samples (April-July) from an intensive agricultural region in Southern Germany. Environ. Sci. Pollut. Res. 2021. [CrossRef] [PubMed]

61. The Associated Press. German Beekeepers Stage Sticky Protest on Ministry Steps. abcNEWS. 15 January 2020. Available online: https://abcnews.go.com/International/wireStory/german-beekeepers-stage-sticky-protest-ministry-steps-68298634 (accessed on 12 March 2021).

62. Odemer, R.; Alkassab, A.T.; Bischoff, G.; Frommberger, M.; Wernecke, A.; Wirtz, I.P.; Pistorius, J.; Odemer, F. Chronic high glyphosate exposure delays individual worker bee (Apis Mellifera L.) development under field conditions. Insects 2020, 11, 664. [CrossRef] [PubMed] 
63. Andreo-Martínez, P.; Oliva, J.; Giménez-Castillo, J.J.; Motas, M.; Quesada-Medina, J.; Cámara, M.Á. Science production of pesticide residues in honey research: A descriptive bibliometric study. Environ. Toxicol. Pharmacol. 2020, 79. [CrossRef]

64. European Comision. National Apiculture Programmes. 2020. Available online: https://ec.europa.eu/info/foodfarming-fisheries/animals-and-animal-products/animal-products/honey/national-apiculture-programmes_en. (accessed on 12 March 2021).

65. APIA. Programul National Apicol. 2019. Available online: http://www.apia.org.ro/files/pages_files/19-05-27-10-13-56Ghidul_ PNA_2019_editia_II_REVIZIA_2_21.05.2019.pdf (accessed on 12 March 2021).

66. Guvernul Romaniei. Hotararea Nr. 339 Din 30 Aprilie 2020 Privind Aprobarea Programului National Apicol Pentru Perioada 2020-2022, a Normelor de Aplicare, Precum Si a Valorii Sprijinului Financiar. 2020. Available online: http:/ / legislatie.just.ro/ Public/DetaliiDocument/225430 (accessed on 12 March 2021).

67. Sub 1\% din Totalul Apicultorilor din Romania, Certificati Ecologic. ecoFerma. 25 September 2018. Available online: https: / / www.eco-ferma.ro/sub-1-din-totalul-apicultorilor-din-romania-certificati-ecologic/ (accessed on 12 March 2021).

68. Wright, K.B. Researching internet-based populations: Advantages and disadvantages of online survey research, online questionnaire authoring software packages, and web survey services. J. Comput. Commun. 2005, 10. [CrossRef] 